\title{
Parasitic fauna of the invasive house sparrow (Passer domesticus) from Ñuble region, Chile: an example of co-introduced parasites
}

\author{
Fauna parasítica do pardal invasor (Passer domesticus) da região de Ñuble, \\ Chile: um exemplo de parasitas co-introduzidos
}

\begin{abstract}
Pablo Oyarzún-Ruiz'1,2 (1D; Guissel Cárdenas¹; María Carolina Silva-de la Fuente ${ }^{3}$ (D); Nicolás Martin; Sergey Mironov ${ }^{4}$ (D); Armando Cicchino5; John Mike Kinsella6; Lucila Moreno7* (1); Daniel González-Acuña ${ }^{1 \dagger}$

${ }^{1}$ Laboratorio de Parásitos y Enfermedades en Fauna Silvestre, Facultad de Ciencias Veterinarias, Universidad de Concepción, Chillán, Chile ${ }^{2}$ Becario ANID Programa de Doctorado en Ciencias Veterinarias, Facultad de Ciencias Veterinarias, Universidad de Concepción, Chillán, Chile ${ }^{3}$ Instituto de Medicina Preventiva Veterinaria, Universidad Austral de Chile, Valdivia, Chile

${ }^{4}$ Zoological Institute, Russian Academy of Sciences, Universitetskaya Embankment 1, Saint Petersburg, Russia ${ }^{5}$ Universidad Nacional de Mar del Plata, Mar del Plata, Argentina ${ }^{6}$ Helm West Lab, Missoula, MT, USA

${ }^{7}$ Departamento de Zoología, Facultad de Ciencias Naturales y Oceanográficas, Universidad de Concepción, Barrio Universitario, Concepción, Chile

${ }^{\dagger}$ In memoriam
\end{abstract}

How to cite: Oyarzún-Ruiz P, Cárdenas G, Silva-de la Fuente MC, Martin N, Mironov S, Cicchino A, et al. Parasitic fauna of the invasive house sparrow (Passer domesticus) from Ñuble region, Chile: an example of co-introduced parasites. Braz J Vet Parasitol 2021; 30(3): e004221. https://doi.org/10.1590/S1984-29612021068

\begin{abstract}
Invasive species impact native wildlife in several ways, as they compete for resources and may transmit their specific pathogens. However, the potential consequences of co-introduced parasites are not fully understood. While the house sparrow (Passer domesticus) was introduced in Chile about a century ago, no data are available regarding its parasites. Thus, the aim of the present study was to determine the parasitic fauna of this avian invader and to determine whether there are co-introduced/co-invasive parasites shared with native birds. One hundred and eight birds were collected from three different localities in the Nuble region of Chile, and a complete parasitic necropsy was performed in the laboratory. Twenty-three (21.3\%) were parasitized by six arthropod species and four (3.7\%) were parasitized by two helminth species. Four out of eight taxa are reported for the first time in Chile; among them, three arthropod parasites and the tapeworm, Anonchotaenia globata, are considered as co-introduced parasites. Only A. globata is a potential co-invasive parasite given its low degree specificity in terms of its definitive hosts. Future research should examine whether additional co-introduced/co-invasive parasites have been brought by the house sparrow, and what their potential consequences might be on the health of native birds in Chile.
\end{abstract}

Keywords: Acari, Phthiraptera, Cestoda, Acanthocephala, co-introduced parasites, co-invasive parasites.

\section{Resumo}

As espécies invasoras de vertebrados competem com espécies nativas no uso de recursos e transmitem patógenos. Contudo as consequências da co-introdução de parasitos permanecem pouco estudadas. O pardal (Passer domesticus) foi introduzido há um século no Chile, porém não existem dados sobre seus parasitos. O objetivo do estudo foi investigar a fauna parasitária e avaliar se existem espécies co-introduzidas/co-invasivas compartilhadas com as espécies de aves nativas do Chile. Um total de 108 aves foram coletadas em diferentes localidades da região de Ñuble. Seis espécies de artrópodes parasitos foram coletadas de $23(21,3 \%$ aves. Quatro aves (3,7\%) estavam parasitadas por duas espécies de helmintos. Quatro de um total de oito espécies de parasitos correspondem aos primeiros relatos para o Chile. Três 
artrópodes parasitos e o helminto Anonchotaenia globata são considerados parasitos co-introduzidos no país. Apenas A. globata possui potencial para ser considerada uma espécie co-invasiva, pois pode parasitar Passeriformes em geral. Pesquisas futuras devem investigar se os demais parasitos identificados neste estudo correspondem a espécies cointroduzidas ou co-invasoras e avaliar as possíveis consequências na saúde das aves nativas do país.

Palavras-chave: Acari, Phthiraptera, Cestoda, Acanthocephala, parasitas co-introduzidos, parasitas co-invasivos.

\section{Introduction}

Invasive species can pose a major threat causing the loss of biodiversity. They can have direct impacts on native species, as they may compete for resources or engage in predation; they sometimes also indirectly modify habitats and transmit pathogens (Lymbery et al., 2014). A species may invade a new area as a result of anthropic modifications to ecosystems and/or deliberate releases in new areas (Taraschewski, 2006; Lymbery et al., 2014). However, an introduced species will become invasive only when it overcomes the following barriers: it invades a new location, survives, reproduces, and ultimately spreads (Lymbery et al., 2014).

According to the definitions by Lymbery et al. (2014), a co-introduced parasite is a species that enters a new area together with the introduced host; meanwhile, a co-invasive parasite is one that has been co-introduced and switched from its original host to a native host that is followed by the potential emergence of new infections/infestations. That being said, the barriers described for the introduced hosts should also be overcome by the parasites, as they may then be able to parasitize native hosts in the new area, thus becoming an invasive parasite.

The parasites brought by introduced hosts may play an important role, as they may affect the success in establishment of their hosts in new areas. When some component of this parasitic fauna is lost in the process of introduction, probability establishment of the introduced host may be enhanced as supported by the enemy-release hypothesis (Torchin et al., 2003; Taraschewski, 2006; Poulin, 2017).

Also, parasites with complex life cycles requiring at least two different hosts would be suppressed in the new territory, if there are no compatible intermediate hosts. Further, if there is an important bottleneck for the introduced host population, this also could impact the dynamics of parasites, thus preventing transmission between individuals (Torchin et al., 2003; Taraschewski, 2006; MacLeod et al., 2010). Once these parasites have successfully established, they could infect competent native hosts in their life cycle, with potential negative effects given the absence of the co-evolutionary adaptation in to native hosts (Taraschewski, 2006; Lymbery et al., 2014). Conversely, the introduced host could be parasitized by native parasites, i.e., the case of a spillback, which could have consequences for the dynamics of these parasites with potentially deleterious results over native hosts (Taraschewski, 2006; Lymbery et al., 2014; Poulin, 2017).

The house sparrow (Passer domesticus Linnaeus, 1758) (Passeriformes: Passeridae) is a gregarious and mostly granivorous bird. It is considered a synanthropic animal because it is strongly associated with human settlements (Martínez \& González, 2017). This Eurasian bird has been introduced all over the world, with the exception of the polar regions (Anderson, 2006). In South America, this bird was intentionally introduced in 1872 and 1873 in Buenos Aires, Argentina, and then in several other countries, including Peru, Brazil, and Uruguay. These populations have expanded to neighboring countries (Anderson, 2006). Meanwhile, it was introduced to Chile from Europe in 1904 (Anderson, 2006; Martínez \& González, 2017). Currently, this allochthonous species is distributed from Arica to Navarino island, including Juan Fernández Archipelago and Easter Island, thus, establishing itself in almost every region of the country (Martínez \& González, 2017).

Most records of parasites of the house sparrow come from its original range in Asia and Europe (e.g., Brown \& Wilson, 1975; Ozmen et al., 2013; Holand et al., 2013; Abdelmageed et al., 2018). Over 60 species of arthropod parasites have been reported from the house sparrow in Europe, while only half of these taxa have been found in North America (Brown \& Wilson, 1975). A similar situation has been observed for endoparasites, as approximately 16 species have been reported in Europe (Martínez et al., 1977; Illescas-Gómez \& López-Roman, 1980), while in the invaded countries, only a small part of this richness has been recorded, such as the 5-9 species recorded in Brazil (Brasil \& Amato, 1992; Calegaro-Marques \& Amato, 2010). Thus, in South America, there are noticeably fewer species of ecto- and endoparasites than have been reported from the house sparrow in its primary range, although these data came mostly from Brazil (e.g., Brasil \& Amato, 1992; Calegaro-Marques \& Amato, 2010; Santos et al., 2018, $2020 a$, b). In Chile, there are scarce reports about the parasite fauna of alien hosts, with some examples noted for the monk parakeet (Myopsitta monachus (Boddaert, 1783) (Psittacidae), rock pigeon (Columba livia Gmelin, 1789) (Columbidae), and California quail (Callipepla californica (Shaw, 1798) (Odontophoridae) (Briceño et al., 2017, 2021; Oyarzún-Ruiz \& González-Acuña, 2021). Although the house sparrow was introduced to Chile about a century 
ago (Anderson, 2006), there are no thorough investigations of its parasites. We present for first time, the result of investigations of the arthropods and helminths parasites associated with this invasive species and discuss the potential implications of co-introduced parasites.

\section{Materials and Methods}

\section{Host collection}

Considering that the house sparrow is catalogued as an avian pest in Chile, its capture and hunting is allowed with no limitations, as stipulated in the Hunting Law of the State (Chile, 2017). Thus, a total of 108 house sparrows (96 adult and 12 juvenile birds) were collected from the Ñuble region, Chile, in 2019. Among these, 76 birds from the Chillán campus, Universidad de Concepción, Chillán (S36³5'52.746" W724'53.554"), were captured using a mist-net. These birds were euthanized through cervical dislocation, which is considered as an appropriate euthanasia method for birds weighting < $3 \mathrm{~kg}$ (Charbonneau et al., 2010). Twenty-six birds from Las Mariposas (S36 ${ }^{\circ} 37^{\prime} 51.533^{\prime \prime}$ W72 $2^{\prime} 27.262^{\prime \prime}$ ) were shot using a $5.5 \mathrm{~mm}$ air rifle, and six birds from Chillán Viejo (S36 37'25.647" W72 ${ }^{\circ} 7^{\prime} 57.514^{\prime \prime}$ ) were found dead and collected by students, who delivered them to us for examination. Each collected bird was individually placed in a hermetic plastic bag to avoid the loss of arthropod parasites. All birds were transported for parasitological examination at Laboratorio de Parásitos y Enfermedades de Fauna Silvestre, Facultad de Ciencias Veterinarias, Universidad de Concepción, Chillán, Chile. The sex of each bird was determined according to its sexual dichromatism (Martínez \& González, 2017), and then subsequently confirmed through the inspection of its gonads. Age was also determined according to the presence/absence of the bursa of Fabricius, both on necropsy.

\section{Collection, preparation, and identification of arthropods}

For the collection of arthropods, the feathers of the head, body, wings, and rectrices were first inspected under a stereomicroscope. Then, the "dust-ruffling" technique described by Walther \& Clayton (1997) was used to collect the lice and feather mites, which were not collected during visible inspection. Once the organs were removed for helminthological inspection, the body of every bird (the head was not immersed in the solution) was washed in $1 \mathrm{~L}$ of tap water with $10 \mathrm{~mL}$ of liquid soap (Galloway, 2005). Then, after several repetitive washings, the sediment was examined under a stereomicroscope to collect ectoparasites. The nasal cavity washing technique was performed after washing the birds' bodies. Nasal mites were initially collected following the modified Yunker's method described by Wilson (1964), using nasal flushing with a tap water-soap solution. Then, the skin of the head was pulled back and the skull disarticulated, so nasal sinuses, nasal turbinates, orbital cavities, and nares were exposed and inspected under a stereomicroscope to collect these mites (Fain, 1957). All collected arthropods were washed using a water-soap solution and rinsed with tap water for about 20 minutes to remove the soap before preservation. All collected arthropods were stored in $70 \%$ ethanol.

Feather mites were cleared in Nesbit solution and in a thermal bath (Dry Bath Incubator MK2000-1) at $70^{\circ} \mathrm{C}$ for 10 minutes. Nasal mites were cleared in $10 \% \mathrm{KOH}$ and in a thermal bath at $80^{\circ} \mathrm{C}$ for 15 minutes. Then, all mites were mounted onto slides containing Berlese' medium (Krantz \& Walter, 2009). Lice were cleared with 20\% KOH, then dehydrated in a series of alcohol concentrations (40\%, 80\%, and 100\%), cleared in clove oil for 24 hours, and mounted onto slides with Canada balsam (Palma, 1978; Price et al., 2003). Feather mites were classified according to the descriptions of Atyeo \& Braasch (1966), Domrow (1987), and Horn et al. (2018); nasal mites were classified according to Fain (1957) and Pence (1975), and lice were classified according to the methods of Giebel (1874), Piaget (1880), Price (1975), Eichler (1954), Price et al. (2003) and Gustafsson et al. (2019).

\section{Collection, preparation, and identification of helminths}

Parasitic necropsy was performed following the methods of Lutz et al. (2017). The eyes, esophagus, gastrointestinal tract, tracheae, lungs, heart, liver, gallbladder, kidneys, bursa of Fabricius, subcutaneous tissue, and articulations were examined under a stereomicroscope. Every organ was gently crushed in citrated saline, then placed in a closed container and shaken vigorously, followed by repetitive sedimentations. Once all organs were removed, the coelomic cavity was washed using citrated saline. The sediment of every organ and cavity was examined using a stereomicroscope. All collected helminths were relaxed in saline and preserved in $80 \%$ ethanol according to the methods of Lutz et al. (2017), and Oyarzún-Ruiz \& González-Acuña (2020). 
Regarding the helminth preparation, acanthocephalans were cleared in a temporary preparation with glycerin alcohol for at least 24 hours. Meanwhile, tapeworms were stained using Alum carmine stain, dehydrated in a series of alcohol concentrations (70\%,80\%,96\%, and 100\%), cleared in clove oil, and mounted onto slides using Canada balsam (Lutz et al., 2017; Oyarzún-Ruiz \& González-Acuña, 2020). Acanthocephalans were identified according to the approaches detailed by Petrochenko (1958), Yamaguti (1963), and Amin \& Dailey (1998). Tapeworms were classified according to Rausch \& Morgan (1947), Yamaguti (1959), Mariaux (1991), and Khalil et al. (1994).

Furthermore, feces were collected from the cloaca and preserved in $80 \%$ ethanol for posterior coprological analysis. A simple flotation technique was performed using saturated saline solution to detect parasite oocysts and eggs (Dryden et al., 2005).

\section{Data analysis}

Prevalence $(P)$, intensity $(I)$, range $(R)$, mean intensity $\left({ }_{M} I\right)$, and mean abundance $\left({ }_{M} A\right)$ were calculated and interpreted according to Bush et al. (1997). Furthermore, the sex ratio, and stage of development ratio were estimated for lice and mites. Sex ratio was expressed as proportion of males, i.e., males/(males + females), and the stages of development ratio was expressed as proportion of adult, i.e. adults/(adults + nymphs). Under the term nymph, we mean all preimaginal instars for mites (tritonymphs, protonymphs and larvae) and lice (all three nymphal stages).

Arthropod parasites and helminths were observed and photographed using optic (Leica DM1000) and scanning electron microscopes (Hitachi SU3500). All parasites are deposited in the parasitological collection of the Laboratorio de Parásitos y Enfermedades de Fauna Silvestre, Universidad de Concepción.

\section{Results}

Twenty-three of 108 birds (21.3\%) were infested by arthropods. Of these, 12 birds (11.11\%) were parasitized by mites of the following species: a nasal mite, Rhinonyssidae gen. sp. (1.85\%), was collected from nasal cavities after nasal flushing; the feather mite, Proctophyllodes troncatus Robin, 1877 (Proctophyllodidae) (10.19\%), was collected from wing feathers; the mesostigmatid mite, Ornithonyssus bursa Berlese, 1888 (Macronyssidae) (0.93\%), was collected from the body surface. Also, 13 birds (12.04\%) were parasitized by three species of chewing lice isolated from the flight and body feathers: Brueelia cyclothorax (Burmeister, 1838) (Philopteridae) (10.19\%), Myrsidea quadrifasciata (Piaget, 1880) (Menoponidae) (0.93\%), and Menacanthus eurysternus Burmeister, 1838 (Menoponidae) (5.56\%) (Table 1) (Figures 1-5).

Four birds (3.7\%) were parasitized by helminths. Two species were reported: Mediorhynchus papillosus Van Cleave, 1916 (Acanthocephala: Giganthorhynchidae) (1.85\%), and Anonchotaenia globata (von Linstow, 1879) (Cestoda: Paruterinidae) (1.85\%), both from the duodenum (Table 1, Figure 6). No protozoa parasites were detected during the coprological analyses. The sex ratio, and stage of development ratio of mites and lice are shown in Table 2.

\section{Discussion}

A total of eight taxa were collected: six arthropods and two helminths, of which four were recorded for first time in Chile (see Table 1). Furthermore, in terms of prevalence, the arthropods were the dominant group of parasites in the present study (21.3\%), that contrasts with helminths (3.7\%).

Proctophyllodes is considered the most speciose among all feather mite genera, with over 170 species infesting 35 families of birds belonging to the order Passeriformes (Atyeo \& Braasch, 1966; Mironov, 2012). Proctophyllodes troncatus was originally described from two species of sparrows, P. domesticus and Passer montanus, in Europe (Robin \& Mégnin, 1877). The first detailed review of world distribution of Pr. troncatus on sparrows was carried out by Gaud \& Atyeo (1976), who reported these mites on the house sparrow in its native range (Europe, Northern Africa, Middle East, Iran, and Kashmir), and in countries where it was introduced (Argentina, Brazil, USA, and Australia), including such islands as Bermuda and Hawaii. Further, it was reported from this host in many European and Asian countries (Mironov, 1996, 1997; Kolarova \& Mitov, 2008; Gürler et al., 2013, Moodi et al., 2014), in Azores archipelago (Rodrigues et al., 2015), Brazil (Hernandes \& Flechtmann, 2020), USA and Canada (Brown \& Wilson, 1975; Byers \& Proctor, 2013). Additionally, Pr. troncatus was recorded on related species of sparrows, Passer hispaniolensis, P. montanus, and Passer rutilans from their corresponding ranges in Europe, Asia, and Northern Africa (Atyeo \& Braasch, 1966; Gaud \& Atyeo, 1976; Mironov, 1996; Kolarova \& Mitov, 2008; Gürler et al., 2013). Thus Pr. troncatus appears to be restricted the bird genus Passer, although it is interesting to note that on P. domesticus 
Table 1. Parasitological descriptors and sites of collection for arthropods and helminths recorded from 108 house sparrows (Passer domesticus) collected in Ñuble region, Chile.

\begin{tabular}{|c|c|c|c|c|c|c|c|}
\hline & $\mathbf{N}$ & $\mathbf{P}(\%)$ & I & $\mathbf{R}$ & $M^{I}$ & ${ }_{\mathrm{M}} \mathrm{A}$ & $\begin{array}{l}\text { Site of } \\
\text { collection }\end{array}$ \\
\hline Acari & 12 & 11.11 & & & & & \\
\hline \multicolumn{8}{|l|}{ Rhinonyssidae } \\
\hline $\begin{array}{l}\text { Rhinonyssidae gen., sp. } \\
\text { (n) }\end{array}$ & 2 & 1.85 & 2 & 1 & 1.00 & 0.02 & Nares \\
\hline \multicolumn{8}{|l|}{ Proctophyllodidae } \\
\hline $\begin{array}{l}\text { Proctophyllodes troncatus } \\
\qquad(a, n)^{+\phi}\end{array}$ & 11 & 10.19 & 62 & $1-10$ & 5.64 & 0.57 & $\begin{array}{l}\text { Wing } \\
\text { feathers }\end{array}$ \\
\hline \multicolumn{8}{|l|}{ Macronyssidae } \\
\hline Ornithonyssus bursa $(\mathrm{a}, \mathrm{n})$ & 1 & 0.93 & 298 & 298 & 298.00 & 2.76 & $\begin{array}{l}\text { Body } \\
\text { surface }\end{array}$ \\
\hline Phthiraptera & 13 & 12.04 & & & & & \\
\hline \multicolumn{8}{|l|}{ Philopteridae } \\
\hline $\begin{array}{l}\text { Brueelia cyclothorax } \\
\qquad(a, n)^{+\phi}\end{array}$ & 11 & 10.19 & 95 & $1-23$ & 8.64 & 0.88 & $\begin{array}{l}\text { Body } \\
\text { feathers }\end{array}$ \\
\hline \multicolumn{8}{|l|}{ Menoponidae } \\
\hline $\begin{array}{l}\text { Myrsidea quadrifasciata } \\
\qquad(a, n)^{\dagger \phi}\end{array}$ & 1 & 0.93 & 8 & 8 & 8.00 & 0.07 & $\begin{array}{l}\text { Body } \\
\text { feathers }\end{array}$ \\
\hline $\begin{array}{l}\text { Menacanthus eurysternus } \\
\qquad(a, n)\end{array}$ & 6 & 5.56 & 111 & $1-83$ & 18.50 & 1.03 & $\begin{array}{l}\text { Body } \\
\text { feathers }\end{array}$ \\
\hline Acanthocephala & 2 & 1.85 & & & & & \\
\hline \multicolumn{8}{|l|}{ Giganthorhynchidae } \\
\hline $\begin{array}{l}\text { Mediorhynchus papillosus } \\
\text { (a) }\end{array}$ & 2 & 1.85 & 9 & $3-6$ & 4.50 & 0.08 & Duodenum \\
\hline Cestoda & 2 & 1.85 & & & & & \\
\hline \multicolumn{8}{|l|}{ Paruterinidae } \\
\hline $\begin{array}{l}\text { Anonchotaenia globata } \\
\qquad(\mathrm{m})^{\dagger \phi}\end{array}$ & 2 & 1.85 & 11 & $2-9$ & 5.50 & 0.10 & Duodenum \\
\hline
\end{tabular}

Abbreviations and symbols. $\mathrm{N}=$ number of parasitized birds; $\mathrm{a}=$ adult, $\mathrm{n}=$ nymph, $\mathrm{m}=$ mature worm, $\mathrm{P}=\mathrm{Prevalence}, \mathrm{I}=$ intensity of infection,

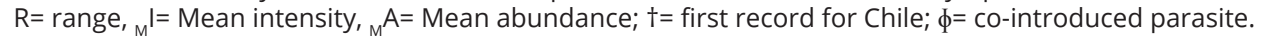

and P. montanus in the oriental part of Asia (India, China) and on introduced populations of the former host in South Africa and Reunion Island, this mite is replaced by another species, Proctophyllodes orientalis Gaud, 1953 (Gaud \& Atyeo 1976).

Ornithonyssus bursa, also known as the tropical fowl mite, is a hematophagous mite distributed over tropical, subtropical, and temperate areas (Arrabal et al., 2012; Mašán et al., 2014; Lareschi et al., 2017), and is considered as a rare mite in Europe (Mašán et al., 2014). According to Mori et al. (2019), it is an introduced parasite in the Old World. This mite has been isolated from hosts of various passerine families, e.g., in Corcoracidae, Furnariidae, Hirundinidae, Icteridae, Sturnidae, Thraupidae, Troglodytidae, and Tyrannidae, in Argentina (Arrabal et al., 2012), Brazil (Mascarenhas et al., 2009; Bassini-Silva et al., 2019), and Australia (Domrow, 1987), and it has also been found on various non-passerine birds - e.g., Accipitridae, Columbidae, Cuculidae, Laridae, Phasianidae, Picidae, Psittacidae, and Strigidae (Fonseca, 1948; Domrow, 1987; Aramburú et al., 2003; Mascarenhas et al., 2009; Arrabal et al., 2012; Coimbra et al., 2012; Santillán et al., 2015; Bassini-Silva et al., 2019; Mori et al., 2019). On the house sparrow, it has been found in Australia (Domrow, 1987), Brazil (Fonseca, 1948; Santos et al., 2020b), and North America (Fonseca, 1948). In spite of 0 . bursa being considered an important parasite of chickens in the 


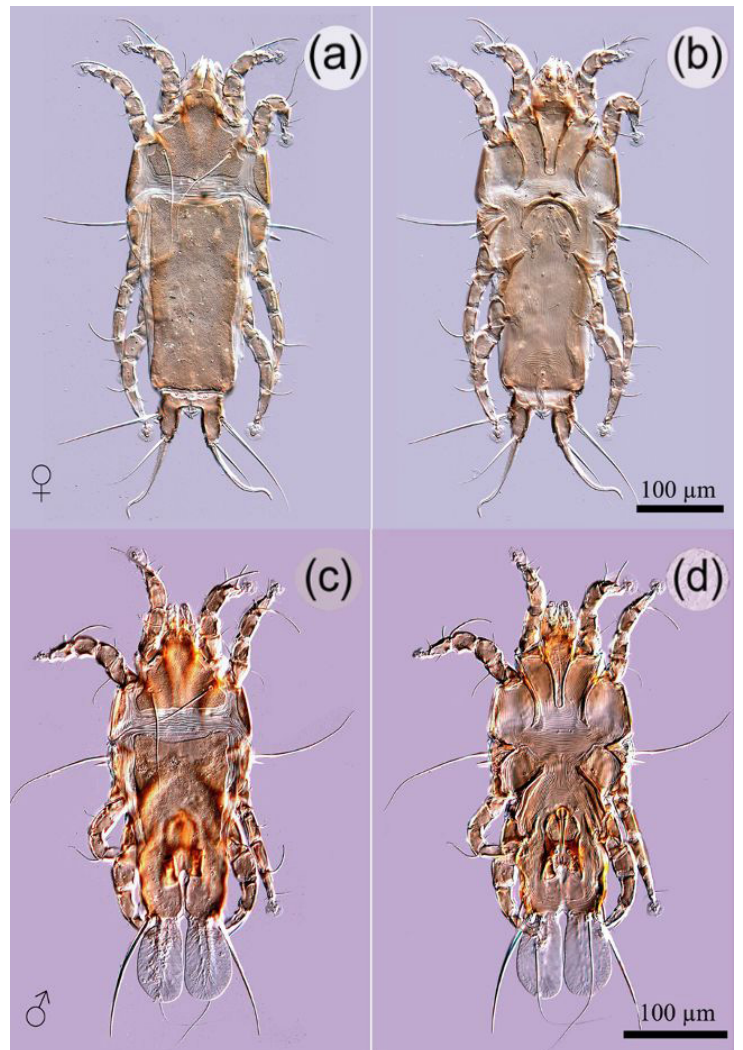

Figure 1. Proctophyllodes troncatus from the house sparrow (Passer domesticus) collected in Ñuble region, Chile. Female mite, dorsal (a) and ventral (b) view. Male mite, dorsal (c) and ventral (d) view.
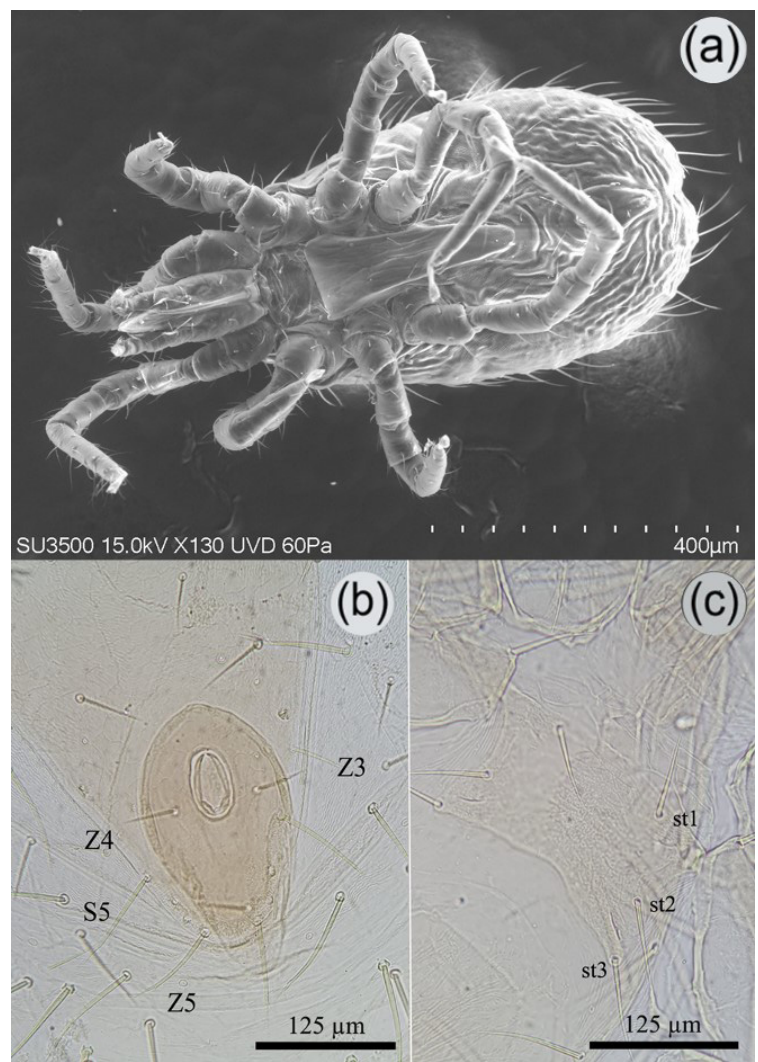

Figure 2. Ornithonyssus bursa, female from the house sparrow (Passer domesticus) collected in Ñuble region, Chile. Ventral view of mite (scanning electronic image) (a); posterior end of opisthosomal plate bearing dorsal setae $(Z 3-Z 5$, S5) and anal shield visible through the transparent body cuticle (b); sternal plate with three sternal setae (st1-3) (c). 


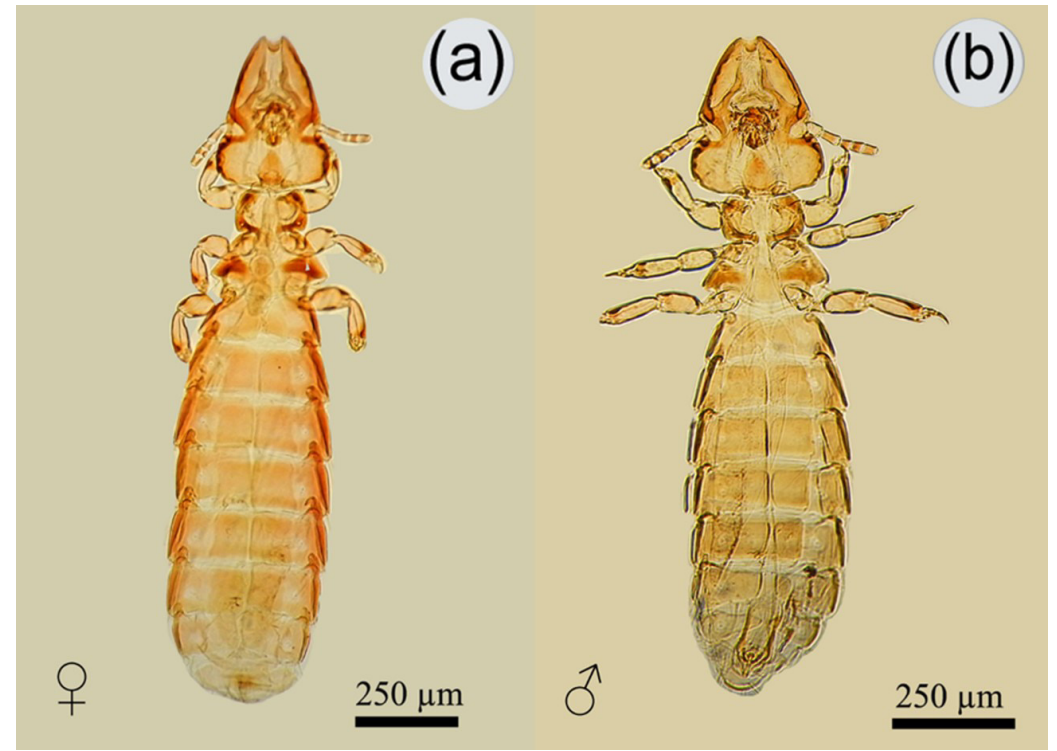

Figure 3. Brueelia cyclothorax from the house sparrow (Passer domesticus) collected in Ñuble region, Chile. Female (a) and male (b).

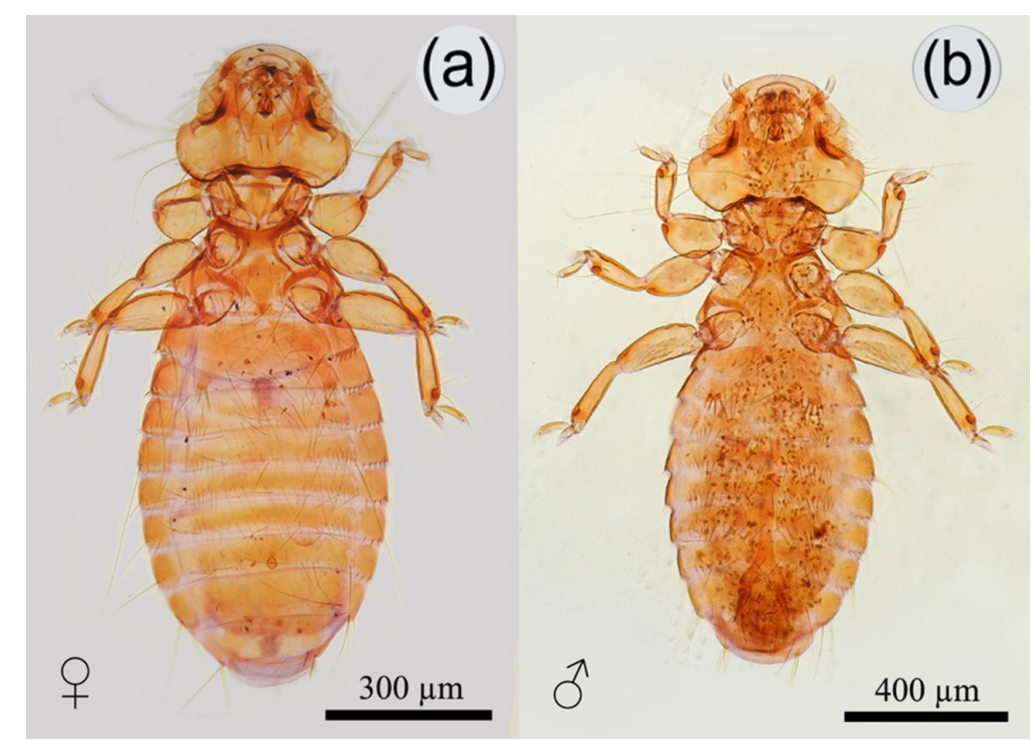

Figure 4. Myrsidea quadrifasciata from the house sparrow (Passer domesticus) collected in Ñuble region, Chile. Female (a) and male (b).

Neotropics (Arrabal et al., 2012; Lareschi et al., 2017; Horn et al., 2018), there are no previous records on domestic fowl from Chile (Alcaíno \& Gorman, 1999). However, it was recently recorded from the invasive monk parakeet in Central Chile (Briceño et al., 2021). Thus, the present record is the first report of this parasite on a wild passerine in Chile. Although this finding constitutes the second record in the country, it is expected to occur on other birds, considering the wide geographic distribution and host range of this mite (Mašán et al., 2014; Lareschi et al., 2017; Arce et al., 2018). Furthermore, this arthropod mostly inhabits the nests of birds and parasitizes chicks during rearing (Aramburú et al., 2003; Arrabal et al., 2012; Lareschi et al., 2017; Horn et al., 2018; Bassini-Silva et al., 2019), with lower prevalence over fledglings and adults (Arce et al., 2018; Mori et al., 2019). Keeping in mind that no chicks and nests were sampled, this biological trait would explain the low prevalence reported here $(0.9 \%)$ when compared to that of other studies ( 50\%) (Arrabal et al., 2012; Santillán et al., 2015). Thus, future studies of this mite in Chile should consider sampling nests and chicks. Although there are no data on its role as a vector of zoonotic agents (Santillán et al., 2015; Lareschi et al., 2017), O. bursa has been found to parasitize humans, when infested nests are located in association with human infrastructure, or after manipulation of infested birds (Oliveira et al., 2012; Bassini-Silva et al., 2019). 


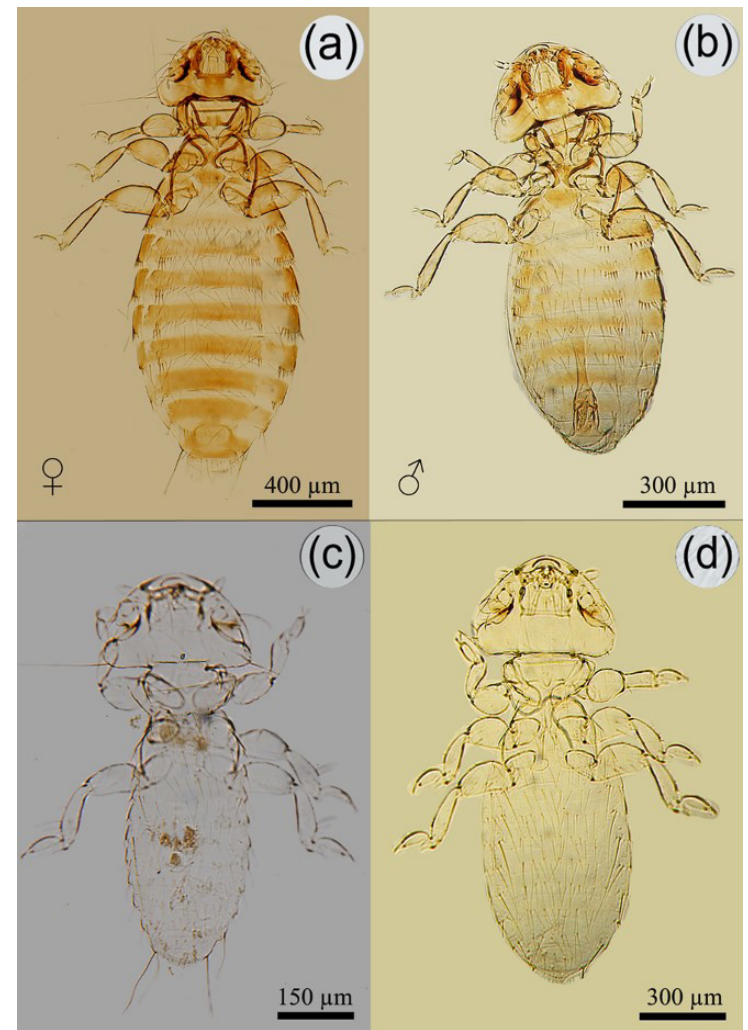

Figure 5. Menacanthus eurysternus from the house sparrow (Passer domesticus) collected in Ñuble region, Chile. Adult female (a) and male (b), nymph I (c), and nymph II (d).

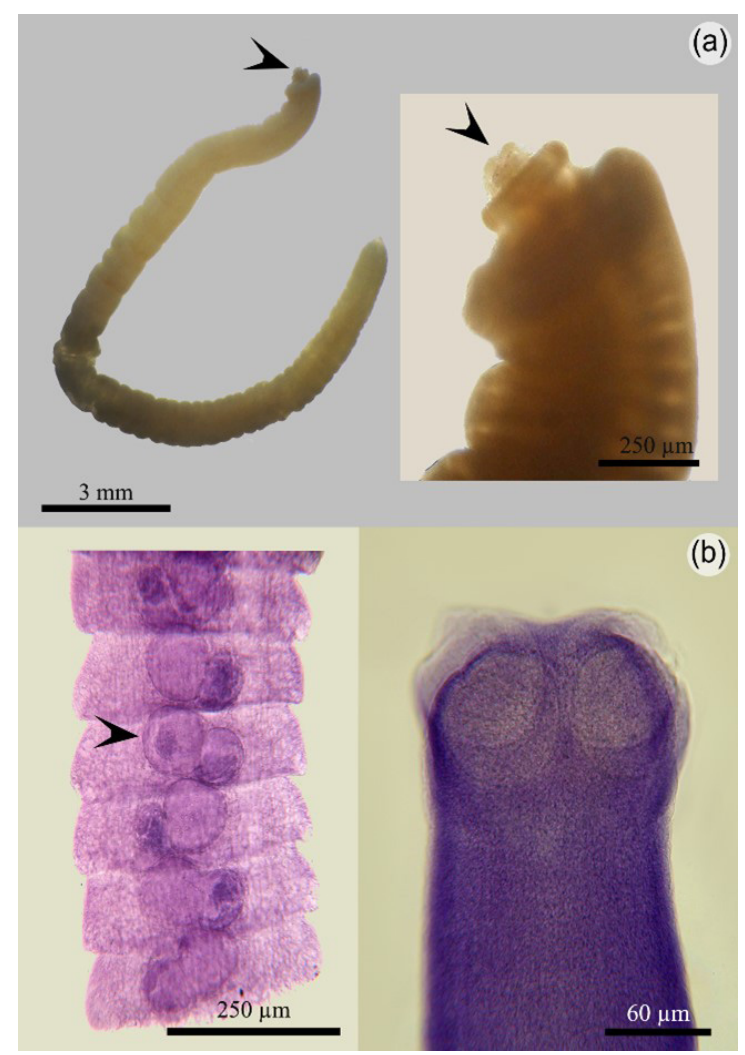

Figure 6. Helminths from the house sparrow (Passer domesticus) collected in Ñuble region, Chile. (a) Mediorhynchus papillosus. Female worm in toto, note its trunk lightly curved dorsally with a conical proboscis covered with hooks (insert); (b) Anonchotaenia globata. Scolex lacking an armed rostellum, also note the four rounded suckers. Mature proglottids with its characteristic paruterine organs in every proglottid. 
Table 2. Stages of development ratio and sex ratio for lice and mites parasitizing the house sparrow (Passer domesticus) collected from Nuble region in Chile.

\begin{tabular}{|c|c|c|c|c|c|c|c|}
\hline & $\mathbf{N}$ & Adults (\%) & Nymphs (\%) & Males (\%) & Females (\%) & $\begin{array}{l}\text { Stage of } \\
\text { development } \\
\text { ratio }\end{array}$ & Sex ratio \\
\hline \multicolumn{8}{|l|}{ Acari } \\
\hline \multicolumn{8}{|l|}{ Rhinonyssidae } \\
\hline $\begin{array}{l}\text { Rhinonyssidae } \\
\text { gen., sp. (n) }\end{array}$ & 2 & 0 & 2 & - & - & - & - \\
\hline \multicolumn{8}{|l|}{ Proctophyllodidae } \\
\hline $\begin{array}{l}\text { Proctophyllodes } \\
\text { troncatus }\end{array}$ & 62 & $48(77.4)$ & $14(22.6)$ & $19(39.6)$ & $29(60.4)$ & 0.8 & 0.4 \\
\hline \multicolumn{8}{|l|}{ Macronyssidae } \\
\hline $\begin{array}{l}\text { Ornithonyssus } \\
\text { bursa }\end{array}$ & 298 & $1(0.3)$ & $297(99.7)$ & 0 & 1 & 0.003 & - \\
\hline \multicolumn{8}{|l|}{ Phthiraptera } \\
\hline \multicolumn{8}{|l|}{ Philopteridae } \\
\hline Brueelia cyclothorax & 95 & $63(66.3)$ & $32(33.7)$ & $33(52.9)$ & $30(47.6)$ & 0.7 & 0.5 \\
\hline \multicolumn{8}{|l|}{ Menoponidae } \\
\hline $\begin{array}{c}\text { Myrsidea } \\
\text { quadrifasciata }\end{array}$ & 8 & $3(37.5)$ & $5(62.5)$ & $1(33.3)$ & $2(66.7)$ & 0.4 & 0.3 \\
\hline $\begin{array}{l}\text { Menacanthus } \\
\text { eurysternus }\end{array}$ & 111 & $44(39.6)$ & $67(60.4)$ & $10(22.7)$ & $34(77.3)$ & 0.4 & 0.2 \\
\hline
\end{tabular}

Abbreviations and symbols. "_" not determined; N= number of parasitized birds; Stages of development ratio= adults/(adults + nymphs); Sex ratio $=$ males $/($ males + females $)$.

Two nasal mites of the family Rhinonyssidae found in two individuals of the house sparrow represented by nymphs were identified only to the family level. Previous records of rhinonyssid species in Chile include Ptilonyssus certhiaxicola Fain, 1964 and Rhinonyssus belenopteri Fain, 1964 isolated from the nasal cavity of Vanellus chilensis (Molina, 1782) (cited as Belenopterus chilensis) originally from Chile but died in Belgium (Fain, 1964); Sternostoma tracheacolum Lawrence, 1948 collected from the mucosal surfaces of the air sacs, bronchi, trachea, and lung of canaries (Serinus canaria Linnaeus, 1758) from a private bird collection in the Metropolitan Region (GonzálezHein et al., 2007). To our knowledge, this is the first report of a nasal mite collected from a wild bird in Chile. The scarce records in Chile could be related to non-inspection of the organs where these mites are found (OyarzúnRuiz \& González-Acuña, 2021). The spectrum of rhinonyssid species recorded in the house sparrow worldwide has included so far seven species from three genera, Ptilonyssus, Sternostoma and Tinaminyssus, the latter is a parasite of C. livia, its records are probably a contamination, a misidentification, or a straggler for the house sparrow (Castro \& Pereira, 1947; Domrow, 1969, 1987; Pence, 1975; Knee et al., 2008; Dimov, 2018, 2020; Santos et al., 2018). Of four species of Ptilonyssus recorded from the house sparrow, only Ptilonyssus degtiarevae Dimov \& Mironov, 2012 is known exclusively from this host in Europe (Dimov \& Mironov, 2012) while, three others, Ptilonyssus hirsti (Castro \& Pereira, 1947), Ptilonyssus icteridius (Strandtmann and Furman, 1956), and Ptilonyssus nudus Berlese \& Trouessart, 1889, are associated with sparrows of the genus Passer and passerines of other families (Dimov, 2020). At present time, it is impossible to evaluate reliably the origin and parasitological importance of rhinonyssid mites found in the house sparrow in Chile; consequently, future surveys of wild birds should include the analysis of the respiratory tract, because there is a possibility that many new host-parasite associations, and very likely undescribed species, might be found in wild birds.

The chewing louse Brueelia Kéler, 1936 is comprised over 300 species found on birds of various avian orders, such as Passeriformes, Coraciiformes, Piciformes, Charadriiformes, and Galliformes, however, the greatest number of species is found in Passeriformes (Gustafsson \& Bush, 2017). Similarly, Myrsidea Waterson, 1951 contains over 350 species, primarily parasitizes members of the order Passeriformes with a few records in the order Apodiformes. Both 
are the most diverse genera from the order Phthiraptera (Price et al., 2003; Valim \& Weckstein, 2013; Gustafsson \& Bush, 2017).

Brueelia cyclothorax and M. quadrifasciata have been recorded on house sparrows in Europe and North America (Brown \& Wilson, 1975; Price et al., 2003; Martín-Mateo, 2006, 2009), and Asia (Saxena et al., 2007; Moodi et al., 2013). The present records reflect their close relationship with the house sparrow, as they can be found across the invaded areas, such as in South America (Hernandes \& Flechtmann, 2020). Both species of lice seem to be restricted to Passer species (Price et al., 2003; Gustafsson \& Bush, 2017); as such, in Chile, they could be considered specialist parasites for the house sparrow, acting as its only host.

Menacanthus eurysternus is a species complex which, unlike most other lice, can be found on hosts from various families of Passeriformes - e.g., Corvidae, Fringillidae, Icteridae, Prunellidae, Remizidae, Sturnidae, and Turdidae, as well as on Piciformes around the world (Price et al., 2003; Galloway, 2005; Martín-Mateo, 2006; Fairn et al., 2014; Galloway et al., 2014), with over 170 avian species counted as hosts (Price, 1975; Price et al., 2003). In terms of house sparrows, this parasite has been recorded in Europe and North America (Brown \& Wilson, 1975; Price et al., 2003; Martín-Mateo, 2006; Byers \& Proctor, 2013), and New Zealand (Galloway, 2005; Palma 2017). In Chile, in addition to the present record, this generalist louse has been isolated only on the austral thrush (González-Acuña et al., 2006; Llanos-Soto et al., 2019). This lower number of hosts in Chile contrasts with the wide range of hosts reported in other South American countries (Cicchino \& Castro, 1998). This could be a direct consequence of a relatively small number of parasitological studies conducted examinations of passerines in Chile. Thus, there is a high probability that additional passerine species could act as hosts of this louse.

Mediorhynchus Van Cleave, 1916 is a cosmopolitan genus comprised of 46 valid species (Moya et al., 2011; Smales, 2011). Mediorynchus papillosus is widely reported to parasitize mainly passerine birds from several families, such as Alaudidae, Hirundinidae, Mimidae, Motacillidae, Parulidae, Passerellidae, Sturnidae, Sylviidae, Turdidae, and Tyrannidae. They have been found in Asia, Europe, North America, and South America (Van Cleave, 1947; Petrochenko, 1958; Yamaguti, 1963; Byrd \& Kellogg, 1971; Lisitsyna, 1994; Amin \& Dailey, 1998). Also, there have been some reports from non-passerine birds, such as those from the orders Accipitriformes, Charadriiformes, Galliformes, Gruiformes, and Piciformes (Yamaguti, 1963; Byrd \& Kellogg, 1971; Lisitsyna, 1994; Amin \& Dailey, 1998). For the house sparrow, this species has been recorded from the United States (Byrd \& Kellogg, 1971), Russia (Petrochenko, 1958), and Brazil (Brasil \& Amato, 1992). A Mediorhynchus sp. has been recorded from this host in Peru and Brazil (Tantaleán et al., 2005; Santos et al., 2020a). In Chile, M. papillosus has been reported in the rufous-collared sparrow Zonotrichia capensis (Müller, 1776) (Passerellidae) (Llanos-Soto et al., 2017) and from the shiny cowbird, Molothrus bonariensis (Gmelin, 1789) (Icteridae) (Mena et al., 2020). This parasite has an indirect life cycle, with darkling beetles (Coleoptera: Tenebrionidae) acting as intermediate hosts (Amin \& Dailey, 1998). According to these authors, the geographic distribution of these beetles in part determines the distribution of this parasite. In fact, Tenebrionidae is reported in Chile with $>400$ species (Elgueta \& Arriagada, 1988) although, to our knowledge, there are no data available to indicate which species might act as an intermediate host. In spite of the fact that the house sparrow is mostly a granivorous bird, it also consumes insects (Martínez \& González, 2017), which explains infections by this parasite. The relatively low parasite load reported here is similar to that of previous reports (e.g., Brasil \& Amato, 1992) and could be related to the host's small size (Van Cleave, 1947).

The genus Anonchotaenia Cohn, 1900 comprises 29 species of tapeworm; its main definitive host includes passerine birds (Phillips et al., 2014). Records in other orders, e.g. Apodiformes and Ciconiiformes, among others, are considered rare or accidental (Khalil et al., 1994). Anonchotaenia globata (von Linstow, 1879) has been recorded in Alaudidae, Fringillidae, Hirundinidae, Icteridae, Motacillidae, Nectariniidae, Paridae, Parulidae, and Sylviidae in Africa and Europe (Rausch \& Morgan, 1947; Illescas-Gómez \& López-Roman, 1980; Mariaux, 1991; Okulewicz \& Sitko, 2012). In house sparrows, this tapeworm has been recorded in Africa, Europe, and North America (Rausch \& Morgan, 1947; Cooper \& Crites, 1974; Martínez et al., 1977; Illescas-Gómez \& López-Roman, 1980). This genus is poorly known from South America, with only eight species reported from Brazil, Paraguay, and Chile (Phillips et al., 2014). Three species have been previously reported in the latter country: Anonchotaenia longiovata (Fuhrmann, 1901) in the austral blackbird, Curaeus curaeus (Molina, 1782) and long-tailed meadowlark, Leistes loyca (Molina, 1782) (Icteridae); Anonchotaenia (Paranonchotaenia) prolixa Phillips, Georgiev, Waeschenbach, Mariaux, 2014 in the white-crested Elaenia, Elaenia albiceps (D'Orbigny \& Lafresnaye, 1837) (Tyrannidae); Anonchotaenia (Paranonchotaenia) macrocephala Fuhrmann, 1908 in Tachycineta leucopyga meyeni (Canabis, 1850) (Hirundinidae) (Rausch \& Morgan, 1947; Soto et al., 2013; Phillips et al., 2014); and Anonchotaenia sp. from C. curaeus (Mena et al., 2020). Thus, the present finding represents the first record for this host in Chile and the third avian host in South America, with 
Sporophila caerulescens (Vieillot, 1823) (Thraupidae) and Z. capensis acting as the other two passerine hosts, although their localities of origin were not detailed (Rausch \& Morgan, 1947). The life cycle of these tapeworms is unknown; however, considering the insectivorous diet of their avian hosts, terrestrial insects are suggested as potential intermediate hosts (Phillips et al., 2014).

A coprological survey was performed in an attempt to collect coccidian parasites; however, there were no positive results. Previous studies have reported the intestinal protozoa, Isospora passeris Levine, 1982 (Martínez et al., 1977; Levine, 1982).

In terms of the proportions of males and females recorded in this study for parasitic arthropods, the feather mite Pr. troncatus and the lice M. quadrifasciata and M. eurysternus were female-biased. Only B. cyclothorax had an equal proportion of females to males. Similar results have been reported in several parasitic arthropod species (e.g., Marshall, 1981; Clayton et al., 1992; San-Martín Órdenes et al., 2005; Surkova et al., 2018). Males are perhaps more mobile and smaller than females, and therefore more prone to detach from or be preyed upon by the host. It has also been observed that females are longer-lived than males, which could explain the higher proportion found (Marshall, 1981). Another explanation for this phenomenon is the proportion of infested hosts (prevalence), determining the degree of isolation and the size of parasite populations, which in turn determines the level of inbreeding (Marshall, 1981; Pap et al., 2013). If inbreeding levels are high, a female-biased sex ratio reduces sibling competition for mates and, by this mechanism, all adults can contribute to reproduction (local mate competition hypothesis) (Pap et al., 2013). Therefore, in parasitic species with low prevalence, female bias should be observed most often (Clayton et al., 1992; Poulin, 1997; Pap et al., 2013). In our study, the prevalence of mites and lice did not exceed $10 \%$, this low prevalence may be an explanation for the female-bias found. In the case of B. cyclothorax, where a similar proportion of males and females was found, this could be explained by the higher mobility described for this louse (Pap et al., 2013), which is reflected in the higher prevalence observed compared to the other two louse species collected.

Concerning the developmental stage of the isolated arthropods, the feather mite Pr. troncatus and the louse B. cyclothorax had a higher proportion of adults than nymphs, while the opposite was true for the lice M. quadrifasciata and $M$. eurysternus. A higher proportion of adults could indicate that the lice population is decreasing, or these proportions are a consequence of the season of the year in which the samples were taken, coinciding with non-reproductive periods of these arthropods since the populations of parasitic arthropods present seasonal changes in the reproductive parameters, which may be particular to each species (Galloway \& Lamb, 2015). To assess this, it would be convenient to sample over several seasons and evaluate the variation in population sizes and reproductive periods of these.

Our study reported low parasite richness and low prevalence for each taxon, with lice and mites being the most prevalent parasites (see Table 1). This finding supports the suggestion that co-introduced parasitic fauna has a low richness and prevalence after introduction (Torchin et al., 2003; Lymbery et al., 2014). Furthermore, the predominance of lice and mites over helminths could be explained given that these parasites are permanent, i.e., do not leave their hosts, and they are transmitted mainly by direct contact between individuals, and they do not require intermediate hosts (McGroarty \& Dobson, 1974), as occurs with the reported helminths. This makes it less likely to find high prevalence in helminths. Additionally, the social behavior of these birds favors the transmission of mites and lice (MacLeod et al., 2010; Tuliozi et al., 2018). In comparison to studies in Europe, there are about 13 species of helminths and over 60 species of ectoparasites recorded in the house sparrow from the Old World (Brown \& Wilson, 1975; Calegaro-Marques \& Amato, 2010), which starkly contrasts with the two helminths and six ectoparasites reported here. However, these results align with previous findings reported from Brazil (Brasil \& Amato, 1992; Calegaro-Marques \& Amato, 2010; Santos et al., 2018, 2020a,b). It is thought that most of these parasites were not co-introduced with their hosts or, if they were, they failed to persist in the new environment because there was an absence of susceptible intermediate hosts, there were adverse climate conditions, or there was a small population size, among other reasons (Torchin et al., 2003; MacLeod et al., 2010). Notwithstanding the above, among the isolated parasites, six out eight taxa were recorded in Chile for the first time.

According to the definitions of Lymbery et al. (2014), Pr. troncatus, B. cyclothorax, and M. quadrifasciata are likely co-introduced parasites, as these ectoparasites are specific to the genus Passer (Price et al., 2003; Mironov, 2012; Hernandes \& Flechtmann, 2020). Although A. globata is a nonspecific helminth (Rausch \& Morgan, 1947; Mariaux, 1991 ), it should also be considered as a co-introduced parasite, but not co-invasive; this could change, if in the future, native hosts are found to be parasitized by this tapeworm (Lymbery et al., 2014). Additionally, whether or 
not 0 . bursa was co-introduced remains doubtful, because it is as a widely distributed parasite in the Americas (Mašán et al., 2014; Lareschi et al., 2017; Arce et al., 2018; Santos et al., 2020b).

Additional research at other locations across Chile will determine if other parasites were co-introduced with the house sparrow, or if there are additional native parasites that may have parasitized this invasive passerine (e.g., Brown \& Wilson, 1975; Calegaro-Marques \& Amato, 2010). The examination of chicks and nests is necessary to study abundance and prevalence of nest-dwelling mites (e.g., Arrabal et al., 2012; Santillán et al., 2015; Mori et al., 2019), and to collect other ectoparasites such as fleas, and ticks (Brown \& Wilson, 1975; Fairn et al., 2014).

In addition to the present study, it is worth noting that among nine avian species introduced to Chile, three species (C. californica, C. livia and M. monachus) are infected with co-introduced parasites (Briceño et al., 2017, 2021; Oyarzún-Ruiz \& González-Acuña, 2021). The discussion about invasive hosts and their co-introduced/co-invasive parasites in the country is not extensive (PNUD, 2017). There is a clear need to continue monitoring these bird species and other exotic species that are widely distributed across the country (see PNUD, 2017), including their parasitic fauna and other pathogens. The goal of future research is to understand zoonotic implications of these parasites, and their impact on native species, especially considering that for most studied cases, such consequences are unknown (Lymbery et al., 2014; Poulin, 2017).

\section{Acknowledgements}

We thankful to Sebastián Muñoz who reviewed the Portuguese "Resumo", and Diane Haughney who reviewed the English text. This study has been funded by the Fondo Nacional de Desarrollo Científico y Tecnológico (FONDECYT) No 1170972 (DGA, LMS).

\section{References}

Abdelmageed E, Abdelgadir M, Babiker MYA, AlRashidi M. Survey of external parasites of house sparrows (Passer domesticus) in Hail Region, Saudi Arabia. Adv Biores 2018; 9(1): 61-66.

Alcaíno H, Gorman T. Parásitos de los animales domésticos en Chile. Parasitol Día 1999; 23(1-2): 33-41. http://dx.doi.org/10.4067/ S0716-07201999000100006.

Amin OM, Dailey MD. Description of Mediorhynchus papillosus (Acanthocephala: Gigantorhnchidae) from a Colorado, U.S.A., Population, with la discussion of morphology and geographical variability. J Helminthol Soc Wash 1998; 65(2): $189-200$.

Anderson TR. Biology of the ubiquitous house sparrow: from genes to populations. New York: Oxford University Press; 2006. http:// dx.doi.org/10.1093/acprof:oso/9780195304114.001.0001.

Aramburú R, Calvo S, Alzugaray M, Cicchino A. Ectoparasitic load of monk parakeet (Myiopsitta monachus, Psittacidae) nestlings. Ornitol Neotrop 2003; 14: 415-418.

Arce SI, Manzoli DE, Saravia-Pietropaolo MJ, Quiroga MA, Antoniazzi LR, Lareschi M, et al. The tropical fowl mite, Ornithonyssus bursa (Acari: Macronyssidae): environmental and host factors associated with its occurrence in Argentine passerine communities. Parasitol Res 2018; 117(10): 3257-3267. http://dx.doi.org/10.1007/s00436-018-6025-1. PMid:30069828.

Arrabal JP, Manzoli DE, Antoniazzi LR, Lareschi M, Beldomenico PM. Prevalencia del ácaro Ornithonyssus bursa Berlese, 1888 (Mesostigmata: Macronyssidae) en un ensamble de aves (Passeriformes) de bosques del centro de la Provincia de Santa Fe, Argentina. Rev Ibero-latinoamericana Parasitol 2012; 71(2): 172-178.

Atyeo WT, Braasch NL. The feather mite genus Proctophyllodes (Sarcoptiformes: proctophyllodidae). Bull Univ Nebr State Mus 1966; 5: 1-354.

Bassini-Silva R, Jacinavicius FC, Hernandes FA, Ochoa R, Bauchan GR, Dowling APG, et al. Dermatitis in humans caused by Ornithonyssus bursa (Berlese 1888) (Mesostigmata: Macronyssidae) and new records from Brazil. Rev Bras Parasitol Vet 2019; 28(1): 134-139. http://dx.doi.org/10.1590/s1984-296120180097. PMid:30785556.

Brasil MC, Amato SB. Análise faunística dos helmintos de pardais (Passer domesticus L., 1758) capturados em Campo Grande, Rio de Janeiro, RJ. Mem Inst Oswaldo Cruz 1992; 87(Suppl. 1): 43-48. http://dx.doi.org/10.1590/S0074-02761992000500009.

Briceño C, Surot D, González-Acuña D, Martínez FJ, Fredes F. Parasitic survey on introduced monk parakeets (Myiopsitta monachus) in Santiago, Chile. Rev Bras Parasito/ Vet 2017; 26(2): 129-135. http://dx.doi.org/10.1590/s1984-29612017023. PMid:28746442.

Briceño C, Yévenes K, Larraechea M, Sandoval-Rodríguez A, Silva-de la Fuente MC, Fredes F, et al. First record of Ornithonyssus bursa (Berlese, 1888) (Mesostigmata: Macronyssidae) parasitizing invasive monk parakeets in Santiago, Chile. Rev Bras Parasitol Vet 2021; 30(1): e024020. http://dx.doi.org/10.1590/s1984-29612021023. PMid:33852700. 
Brown NS, Wilson GI. A comparison of the ectoparasites of the house sparrow (Passer domesticus) from North America and Europe. Am Midl Nat 1975; 94(1): 154-165. http://dx.doi.org/10.2307/2424546.

Bush AO, Lafferty KD, Lotz JM, Shostak AW. Parasitology meets ecology on its own terms: margolis et al. revisited. J Parasitol 1997; 83(4): 575-583. http://dx.doi.org/10.2307/3284227. PMid:9267395.

Byers K, Proctor H. Symbiotic arthropods from the house sparrow (Passer domesticus, Aves: Passeridae) from two locations in Alberta, Canada. Can Entomol 2013; 145(6): 668-673. http://dx.doi.org/10.4039/tce.2013.45.

Byrd EE, Kellogg FE. Mediorhynchus bakeri, a new acanthocephalan (Gigantorhynchidae) from the bob-white, Colinus virginianus virginianus (L.). J Parasitol 1971; 57(1): 137-142. http://dx.doi.org/10.2307/3277769.

Calegaro-Marques C, Amato SB. Helminths of introduced house sparrows (Passer domesticus) in Brazil: does population age affect parasite richness? Iheringia Ser Zool 2010; 100(1): 73-78. http://dx.doi.org/10.1590/S0073-47212010000100010.

Castro MP, Pereira C. Acaros nasicolas (Parasitiformes: Rhinonyssidae) do pardal Passer domesticus L. Archos Inst Biol 1947; 18: 125-133.

Charbonneau R, Niel L, Olfert E, von Keyserlingk M, Griffin G. CACC guidelines on: euthanasia of animals used in science. Ottawa: Canadian Council on Animal Care; 2010.

Chile. Ministerio de Agricultura. Servicio Agrícola y Ganadero - SAG. Ley N¹9.473 y su Reglamento. Santiago de Chile: Servicio Agrícola y Ganadero; 2017.

Cicchino AC, Castro DC. Amblycera. In: Morrone JJ, Coscarón S. Biodiversidad de Artrópodos Argentinos. Buenos Aires: Ediciones Sur; 1998. p. 84-104.

Clayton DH, Gregory RD, Price RD. Comparative ecology of Neotropical bird lice (Insecta: phthiraptera). J Anim Ecol 1992; 61(3): 781-795. http://dx.doi.org/10.2307/5631.

Coimbra MAA, Mascarenhas CS, Müller G, Brum JGW. Phthiraptera and Gamasida parasites of Columbina picui (Temminck) (Columbiformes: Columbidae) in the state of Rio Grande do Sul, southern Brazil. Braz J Biol 2012; 72(3): 583-585. http://dx.doi. org/10.1590/S1519-69842012000300022. PMid:22990830.

Cooper CL, Crites JL. Helminth parasitism in juvenile house sparrows, Passer domesticus (L.), from south bass island, Ohio, including a list of helminths reported from this host in North America. Ohio J Sci 1974; 74(6): 388-389.

Dimov I, Mironov SV. Two new species of nasal mites of the genus Ptilonyssus (Rhinonyssidae) from sparrows from the Leningrad province, Russia. J Hell Vet Med Soc 2012; 63(2): 167-176. http://dx.doi.org/10.12681/jhvms.15432.

Dimov I. Rhinonyssid mites of the northwest of Russia. Saint Petersburg: Zhigulin SV; 2018. [In Russian]

Dimov I. Taxonomic diversity and morphology of mites of the family Rhinonyssidae of the northwest of Russia. Saint Petersburg: Krin; 2020.

Domrow R. Acari Mesostigmata parasitic on Australian vertebrates: an annotated checklist, keys and bibliography. Invertebr Taxon 1987; 1(7): 817-948. http://dx.doi.org/10.1071/IT9870817.

Domrow R. The nasal mites of Queensland birds (Acari: Dermanyssidae, Ereynetidae, and Epidermoptidae). Proc Linn Soc N S W 1969; 93: 297-426.

Dryden MW, Payne PA, Ridley R, Smith V. Comparison of common fecal flotation techniques for the recovery of parasite eggs and oocysts. Vet Ther 2005; 6(1): 15-28. PMid:15906267.

Eichler W. Deutsche Federlinge. I. Genus Brueelia. Nachr naturwiss. Mus Aschaffenburg 1954; 42: 59-66.

Elgueta M, Arriagada G. Estado actual del conocimiento de los coleópteros de Chile (Insecta: coleoptera). Rev Chil Entomol 1988; 17: 5-60.

Fain A. Les acariens de la familles Epidermoptidae et Rhinonyssidae parasites des fosses nasals d'oiseaux au Ruanda-Urundi et au Congo Belge. Ann du Mus R du Congo Belge Tervuren 1957; 60: 1-176.

Fain A. Nouveaux Rhinonyssidae et Ereynetidae parasites nasicoles d'oiseaux (Acarina: mesostigmata et Trombidiformes). Rev Zool Afr 1964; 70: 29-39.

Fairn ER, Hornsby MA, Galloway TD, Barber CA. Ectoparasites of nestling European starlings (Sturnus vulgaris) from a nest box colony in Nova Scotia, Canada. J Acad Entomol Soc 2014; 10: 19-22.

Fonseca F. A monograph of the genera and species of Macronyssidae Oudemans, 1936 (synom: liponissidae Vitzthum, 1931) (Acari). Proc Zoo/ Soc Lond 1948; 118(2): 249-334. http://dx.doi.org/10.1111/j.1096-3642.1948.tb00378.x.

Galloway TD, Lamb RJ. Seasonal population dynamics of four species of chewing lice (Phthiraptera: Menoponidae, Philopteridae) on feral pigeons (Aves: Columbiformes: Columbidae). Can Entomo/ 2015; 147(6): 712-722. http://dx.doi.org/10.4039/tce.2014.84. 
Galloway TD, Proctor HC, Mironov SV. Chewing lice (Insecta: Phthiraptera: Amblycera, Ischnocera) and feather mites (Acari: Astigmatina: Analgoidea, Pterolichoidea): Ectosymbionts of grassland birds in Canada. In: Cárcamo HA, Giberson DJ, editors. Arthropods of Canadian Grasslands: Biodiversity and Systematics: Part 1. Canada: Biological Survey of Canada; 2014. p. $139-188$.

Galloway TD. Ectoparasites from native and introduced birds from Christchurch and surrounding areas, New Zealand. Tuhinga 2005; 16: 13-20.

Gaud J, Atyeo WT. Discordances entre les aires de répartition géographique des parasites et celles de leurs hôtes chez les Sarcoptiformes plumicoles. Acarologia 1976; 18(2): 329-344. PMid:1020635.

Giebel CG. Insecta epizoa. Die auf Säugetieren und Vögeln schmarotzenden Insecten nach Chr. Nitzsch's Nachlass bearbeilet. Leipzig: O. Wigand; 1874. http://dx.doi.org/10.5962/bhl.title.66072.

González-Acuña D, Vergara F, Moreno L, Barrientos C, Ardiles K, Cicchino A. Lice (Insecta: Phthiraptera) from species of the families Furnariidae, Tyrannidae, Turdidae and Icteridae (Aves: Passeriformes) from Chile. Gayana (Concepc) 2006; 70(2): 210-219. http:// dx.doi.org/10.4067/S0717-65382006000200008.

González-Hein G, Fredes F, Hidalgo H. Diagnostic Challenge. J Exot Pet Med 2007; 16(4): 270-272. http://dx.doi.org/10.1053/j. jepm.2007.09.006.

Gürler AT, Mironov SV, Erciyes-Yavuz K. Avian feather mites (Acari: Astigmata) of Samsun, Turkey. Acarologia 2013; 53(1): 17-23. http://dx.doi.org/10.1051/acarologia/20132078.

Gustafsson DR, Bush SE. Morphological revision of the hyperdiverse Brueelia-complex (Insecta: Phthiraptera: Ischnocera: Philopteridae) with new taxa, checklists and generic key. Zootaxa 2017; 4313(1): 1-443. http://dx.doi.org/10.11646/zootaxa.4313.1.1.

Gustafsson DR, Zou F, Oslejskova L, Najer T, Sychra O. Four new species of Brueelia Kéler, 1936 (Phthiraptera: Ischnocera) from African hosts, with a redescription of Nirmus bicurvatus Piaget, 1880. Eur J Taxon 2019; 507(507): 1-48. http://dx.doi.org/10.5852/ ejt.2019.507.

Hernandes FA, Flechtmann CHW. New records of feather mites (Acariformes: Analgoidea, Pterolichoidea) in Piracicaba, SP, Brazil. Entomol Commun 2020; 2: ec02006. http://dx.doi.org/10.37486/2675-1305.ec02006.

Holand H, Jensen H, Tufto J, Sæther B, Ringsby T. Temporal and spatial variation in prevalence of the parasite Syngamus trachea in a metapopulation of house sparrows (Passer domesticus). Parasitology 2013; 140(10): 1275-1286. http://dx.doi.org/10.1017/ S0031182013000735. PMid:23790222.

Horn TB, Granich J, Körbes JH, Da Silva GL, Ferla NJ. Mite fauna (Acari) associated with the poultry industry in different laying hen management systems in Southern Brazil: A species key. Acarologia 2018; 58(1): 140-158. http://dx.doi.org/10.24349/ acarologia/20184233.

Illescas-Gómez P, López-Roman R. Variación en las medidas de Anonchotaenia globata Linstow, 1879 según sus hospedadores. Rev Iber Parasitol 1980; 40(4): 407-415.

Khalil L, Jones A, Bray R. Keys to the cestode parasites of vertebrates. London: CAB International; 1994.

Knee W, Proctor H, Galloway T. Survey of nasal mites (Rhinonyssidae, Ereynetidae, and Turbinoptidae) associated with birds in Alberta and Manitoba, Canada. Can Entomo/ 2008; 140(3): 364-379. http://dx.doi.org/10.4039/n08-017.

Kolarova NT, Mitov PG. Feather mites of the superfamily Analgoidea (Acari: Astigmata) from passerines (Aves: Passeriformes) in South Dobrudzha, Bulgaria. Acta Zool Bulg 2008;(Suppl. 2): 91-102.

Krantz GW, Walter DE. A manual of Acarology. 3rd ed. Lubbock: Texas Tech University Press; 2009.

Lareschi M, Cicuttin GL, De Salvo MN, Ibañez L, Montalti D. The tropical fowl mite Ornithonyssus bursa (Acari: Mesostigmata: Macronyssidae) parasitizing the European starling Sturnus vulgaris (Aves: Passeriformes: Sturnidae), an invasive bird in central Argentina. An approach to the bacterial fauna of this mite. Rev Mex Biodivers 2017; 88(2): 454-458. http://dx.doi.org/10.1016/j. rmb.2017.03.022.

Levine ND. Isospora passeris n. sp. from the house sparrow Passer domesticus, I. lacazei, and related apicomplexan Protozoa. Trans Am Microsc Soc 1982; 101(1): 66-74. http://dx.doi.org/10.2307/3225571.

Lisitsyna OI. The spiny-headed worms of the genus Mediorhynchus (Acanthocephala): bird parasites of the Ukrainian fauna. Vestn Zool 1994; 28(3): 12-18.

Llanos-Soto S, Córdoba M, Moreno L, Kinsella JM, Mironov S, Cicchino A, et al. External and intestinal parasites of the austral thrush Turdus falcklandii (Aves, Turdidae) in central Chile. Rev Bras Parasito/ Vet 2019; 28(3): 432-442. http://dx.doi.org/10.1590/ s1984-29612019067. PMid:31531671.

Llanos-Soto S, Muñoz B, Moreno L, Landaeta-Aqueveque C, Kinsella JM, Mironov S, et al. External and gastrointestinal parasites of the rufous-collared sparrow Zonotrichia capensis (Passeriformes, Emberizidae) in Chile. Braz J Vet Parasitol 2017; 26(3): 314322. http://dx.doi.org/10.1590/s1984-29612017043. PMid:28977245. 
Lutz HL, Tkach VV, Weckstein JD. Methods for specimen-based studies of avian symbionts. In: Webster MS. The Extended Specimen: Emerging Frontiers in Collections-Based Ornithological Research. Boca Raton; CRC Press: 2017. p. 157-183.

Lymbery AJ, Morine M, Kanani HG, Beatty SJ, Morgan DL. Co-invaders: the effects of alien parasites on native hosts. Int J Parasitol Parasites Wildl 2014; 3(2): 171-177. http://dx.doi.org/10.1016/j.ijppaw.2014.04.002. PMid:25180161.

MacLeod CJ, Paterson AM, Tompkins DM, Duncan RP. Parasites lost - do invaders miss the boat or drown on arrival? Ecol Lett 2010; 13(4): 516-527. http://dx.doi.org/10.1111/j.1461-0248.2010.01446.x. PMid:20455925.

Mariaux J. Cestodes of birds from the Ivory Coast. Species of the genus Anonchotaenia Cohn, 1990. Syst Parasitol 1991; 20(2): 109-120. http://dx.doi.org/10.1007/BF00007387.

Marshall AG. The sex ratio in ectoparasitic insects. Ecol Entomo/ 1981; 6(2): 155-174. http://dx.doi.org/10.1111/j.1365-2311.1981. tb00602.x.

Martínez D, González G. Aves de Chile: Guía de campo y breve historia natural. Santiago: Ediciones del Naturalista; 2017.

Martínez F, Hernández S, Calero R, Becerra C, Moreno T, Domínguez de Tena M, et al. Parásitos de aves Passeriformes en la provincia de Córdoba. Rev Iber Parasitol 1977; 37(1-2): 133-141.

Martín-Mateo MP. Diversidad y distribucion de las especies de Mallophaga (Insecta) en Aves y Mamíferos de la comunidad de Madrid. Graellsia 2006; 62(no. extra): 21-32. http://dx.doi.org/10.3989/graellsia.2006.v62.iExtra.108.

Martín-Mateo MP. Fauna Ibérica. Madrid: Museo Nacional de Ciencias Naturales, Consejo Superior de Investigaciones Científicas; 2009. (Ischnocera, Philopteridae; vol. 32).

Mašán P, Fend'a P, Krištofík J, Halliday B. A review of the ectoparasitic mites (Acari: Dermanyssoidea) associated with birds and their nests in Slovakia, with notes on identification of some species. Zootaxa 2014; 3893(1): 77-100. http://dx.doi.org/10.11646/ zootaxa.3893.1.3. PMid:25544512.

Mascarenhas CS, Coimbra MAA, Müller G, Brum JGW. Ocurrence of Ornithonyssus bursa (Berlese, 1888) (Acari: Macronyssidae) on Megascops choliba (tropical screech-owl) and Pitangus sulphuratus (great kiskadee) nestlings in the Rio Grande do Sul State, Brazil. Rev Bras Parasitol Vet 2009; 18(4): 69-70. http://dx.doi.org/10.4322/rbpv.01804013. PMid:20040213.

McGroarty DL, Dobson RC. Ectoparasite populations on house sparrows in Northwestern Indiana. Am Midl Nat 1974; 91 (2): 479486. http://dx.doi.org/10.2307/2424345.

Mena M, Valdebenito JO, Moreno L, Fuentes-Castillo D, Kinsella JM, Mironov S, et al. Parasites of the shiny cowbird, Molothrus bonariensis, and the austral blackbird, Curaeus curaeus, (Passeriformes: Icteridae) in Chile. Rev Bras Parasitol Vet 2020; 29(2): e021819. http://dx.doi.org/10.1590/s1984-29612020022. PMid:32609244.

Mironov SV. Contribution to the feather mites of Switzerland with descriptions of five new species (Acarina: sarcoptiformes). Mitt Schweiz Entomol Ges 1997; 70: 455-471.

Mironov SV. Feather mites of the passerines in the north-west of Russia. Parazitologiya 1996; 30(6): 521-539. [In Russian with English summary].

Mironov SV. New species of the feather mite genus Proctophyllodes Robin, 1877 (Acari: Analgoidea: Proctophyllodidae) from European passerines (Aves: Passeriformes), with an updated checklist of the genus. Acarina (Mosc) 2012; 20(2): $130-158$.

Moodi B, Aliabadian M, Moshaverinia A, Kakhki OM, Faraji F. Mites associated with passerine birds in eastern Iran. Int J Acarol 2014; 40(2): 133-137. http://dx.doi.org/10.1080/01647954.2014.888094.

Moodi B, Aliabadian M, Moshaverinia A, Kakhki OM. New data on the chewing lice (Phthiraptera) of passerine birds in East of Iran. Rev Sci Parasitol 2013; 14(2): 63-68.

Mori E, Sala JP, Fattorini N, Menchetti M, Montalvo T, Senar JC. Ectoparasite sharing among native and invasive birds in a metropolitan area. Parasitol Res 2019; 118(2): 399-409. http://dx.doi.org/10.1007/s00436-018-6174-2. PMid:30565194.

Moya R, Martínez R, Tantaleán M. Nueva especie de Mediorhynchus (Acanthocephala, Gigantorhynchidae) en Turdus chiguanco (Turdidae) de Junín, Perú. Rev Peru Biol 2011; 18(3): 299-302.

Okulewicz A, Sitko J. Parasitic helminthes: probable cause of death of birds. Helminthologia 2012; 49(4): 241-246. http://dx.doi. org/10.2478/s11687-012-0045-7.

Oliveira CB, Tonin AA, Monteiro SG. Parasitismo do ácaro Ornithonyssus bursa em humanos no sul do Brasil. Acta Sci Vet 2012; 40(4): 1091.

Oyarzún-Ruiz P, González-Acuña D. Checklist and state of knowledge of helminths in wild birds from Chile: an update. Austral J Vet Sci 2021; 53(1): 63-72. http://dx.doi.org/10.4067/S0719-81322021000100063.

Oyarzún-Ruiz P, González-Acuña D. Colecta, preparación e identificación de parásitos. Parasitol Latinoam 2020; 69(1): $12-29$. 
Ozmen O, Adanir R, Haligur M, Albayrak T, Kose O, Ipek V. Parasitologic and pathologic observations of the house sparrow (Passer domesticus). J Zoo Wildl Med 2013; 44(3): 564-569. http://dx.doi.org/10.1638/2012-0013R2.1. PMid:24063083.

Palma RL. Phthiraptera (Insecta): a catalogue of parasitic lice from New Zealand. Lincoln, N.Z.: Landcare Research; 2017.

Palma RL. Slide-mounting of lice: a detailed description of the Canada balsam technique. N Z Entomo/ 1978; 6(4): 432-436. http:// dx.doi.org/10.1080/00779962.1978.9722313.

Pap PL, Adam C, Vágási Cl, Benkő Z, Vincze O. Sex ratio and sexual dimorphism of three lice species with contrasting prevalence parasitizing the house sparrow. J Parasito/ 2013; 99(1): 24-30. http://dx.doi.org/10.1645/GE-3157.1. PMid:22924903.

Pence DB. Keys, species and host list, and bibliography for nasal mites of North American birds (Acarina-Rhinonyssinae, Turbinoptinae, Speleognathinae, and Cytoditidae). Lubbock: Texas Tech University; 1975. http://dx.doi.org/10.5962/bhl.title.156478.

Petrochenko VI. Acanthocephala of domestic and wild animals. Moscow: Izdatel'stvo Akademii Nauk SSSR; 1958. (vol. 2).(

Phillips AJ, Georgiev BB, Waeschenbach A, Mariaux J. Two new and two redescribed species of Anonchotaenia (Cestoda: Paruterinidae) from South American birds. Folia Parasitol (Praha) 2014; 61(5): 441-461. http://dx.doi.org/10.14411/fp.2014.058. PMid:25549500.

Piaget E. Les Pédiculines - Essai monographique. Leiden, Netherlands: E. J. Brill; 1880.

Poulin R. Invasion ecology meets parasitology: advances and challenges. Int J Parasitol Parasites Wild/ 2017; 6(3): 361-363. http:// dx.doi.org/10.1016/j.ijppaw.2017.03.006. PMid:30951572.

Poulin R. Population abundance and sex ratio in dioecious helminth parasites. Oecologia 1997; 111(3): 375-380. http://dx.doi. org/10.1007/s004420050248. PMid:28308132.

Price RD, Hellenthal RA, Palma RL, Johnson KP, Clayton DH. The chewing lice: world checklist and biological overview. Illinois: Illinois Natural History Survey Special Publication; 2003.

Price RD. The Menacanthus eurysternus Complex (Mallophaga: Menoponidae) of the Passeriformes and Piciformes (Aves). Ann Entomol Soc Am 1975; 68(4): 617-622. http://dx.doi.org/10.1093/aesa/68.4.617.

Programa de las Naciones Unidas para el Desarrollo - PNUD. Catálogo de las especies exóticas asilvestradas/naturalizadas en Chile. Santiago de Chile: Laboratorio de Invasiones Biológicas (LIB), Universidad de Concepción; 2017. Proyecto GEF/MMA/ PNUD Fortalecimiento de los Marcos Nacionales para la Gobernabilidad de las Especies Exóticas Invasoras: Proyecto Piloto en el Archipiélago de Juan Fernández.

Rausch R, Morgan BB. The genus Anonchotaenia (Cestoda: Dilepididae) from North American birds, with the description of a new species. Trans Am Microsc Soc 1947; 66(2): 203-211. http://dx.doi.org/10.2307/3223251. PMid:20266405.

Robin C, Megnin P. Mémoire sur les Sarcoptides plumicoles. Journal de l'anatomie et de la physiologie normales et pathologiques de l'homme et des animaux, 1877;13:209-248, 391-429, 498-520, 629-656 + pls. XII, XIII, XXII-XXIX, XXXVI-XXXVIII.

Rodrigues P, Mironov S, Sychra O, Resendes R, Literak I. Feather mites (Acari, Astigmata) from Azorean passerines (Aves, Passeriformes): lower species richness compared to European mainland. Parasite 2015; 22: 8. http://dx.doi.org/10.1051/ parasite/2015009. PMid:25665827.

San-Martín Órdenes J, Ibánez CB, Contreras LR, Schmäschke R, Daugschies A, González-Acuña D. Ectoparasitismo en tiuque común Milvago chimango chimango (Vieillot, 1816) (Aves, Falconidae) en la zona de Ñuble, Chile. Lundiana 2005; 6(1): 49-55. http:// dx.doi.org/10.35699/2675-5327.2005.22027.

Santillán M, Grande JM, Liébana MS, Martínez P, Díaz LA, Bragagnolo LA, et al. New hosts for the mite Ornithonyssus bursa in Argentina. Med Vet Entomol 2015; 29(4): 439-443. http://dx.doi.org/10.1111/mve.12129. PMid:26258483.

Santos LSS, Mascarenhas CS, Santos PRS, Farias NAR. Rhinonyssidae (Acari) in the house sparrows, Passer domesticus (Linnaeus, 1758) (Passeriformes: Passeridae), from southern Brazil. Rev Bras Parasito/ Vet 2018; 27(4): 597-603. http://dx.doi.org/10.1590/ s1984-296120180064. PMid:30427521.

Santos LSS, Silveira-Mascarenhas C, Santos PRS, Rosa-Farias NA. Helminth fauna of Passer domesticus (Passeriformes: Passeridae) in the southern extreme of Brazil. Rev Mex Biodivers 2020a; 91: e913109. http://dx.doi.org/10.22201/ib.20078706e.2020.91.3109.

Santos LSS, Mascarenhas CS, Santos PRS, Farias NA. Mites Macronyssidae parasites of Passer domesticus (Linnaeus, 1758) (Passeriformes: Passeridae) in the Southern of Brazil. Rev Bras Zoociênc 2020b; 21(1): 1-12.

Saxena AK, Kumar S, Gupta N, Mitra JD, Ali SA, Srivastava R. Distribution pattern of phthirapterans infesting certain common Indian birds. J Parasitol 2007; 93(4): 957-958. http://dx.doi.org/10.1645/GE-978R1.1. PMid:17918388.

Smales LR. Gigantorhynchidae (Acanthocephala) including the description of new species of Mediorhynchus from birds from the Côte d'Ivoire, Africa. Comp Parasitol 2011; 78(2): 316-326. http://dx.doi.org/10.1654/4510.1. 
Soto M, Moreno L, Sepúlveda MS, Kinsella JM, Mironov S, González-Acuña D. First records of parasites from the long-tailed meadowlark Sturnella loyca (Passeriformes: Icteridae) from the Biobío Region, Chile. Rev Mex Biodivers 2013; 84(4): 1316-1320. http://dx.doi.org/10.7550/rmb.34112.

Surkova EN, Korallo-Vinarskaya NP, Vinarski MV, Stanko M, Warburton EM, van der Mescht L, et al. Sexual size dimorphism and sex ratio in arthropod ectoparasites: contrasting patterns at different hierarchical scales. Int J Parasitol 2018; 48(12): 969-978. http://dx.doi.org/10.1016/j.ijpara.2018.05.006. PMid:30076911.

Tantaleán M, Sánchez L, Gómez L, Huiza A. Acantocéfalos del Perú. Rev Peru Biol 2005; 12(1): 83-92.

Taraschewski H. Hosts and parasites as aliens. J Helminthol 2006; 80(2): 99-128. http://dx.doi.org/10.1079/JOH2006364. PMid:16768855.

Torchin ME, Lafferty KD, Dobson AP, McKenzie VJ, Kuris AM. Introduced species and their missing parasites. Nature 2003; 421(6923): 628-630. http://dx.doi.org/10.1038/nature01346. PMid:12571595.

Tuliozi B, Fracasso G, Hoi H, Griggio M. House sparrows' (Passer domesticus) behaviour in a novel environment is modulated by social context and familiarity in a sex-specific manner. Front Zoo/ 2018; 15(1): 16. http://dx.doi.org/10.1186/s12983-018-0267-8. PMid:29721031.

Valim MP, Weckstein JD. A drop in the bucket of the megadiverse chewing louse genus Myrsidea (Phthiraptera, Amblycera, Menoponidae): ten new species from Amazonian Brazil. Folia Parasitol (Praha) 2013; 60(5): 377-400. http://dx.doi.org/10.14411/ fp.2013.040. PMid:24471279.

Van Cleave HJ. The acanthocephalan genus Mediorhynchus, its history and a review of the species occurring in the United States. J Parasitol 1947; 33(4): 297-315. http://dx.doi.org/10.2307/3273358. PMid:20256979.

Walther BA, Clayton DH. Dust-ruffling: a simple method for quantifying ectoparasite loads of live birds. J Field Ornithol 1997; 68(4): 509-518.

Wilson N. An evaluation of Yunker's technique for the recovery of nasal mites from birds. J Med Entomo/ 1964; 1(1): 117. http:// dx.doi.org/10.1093/jmedent/1.1.117. PMid:14188819.

Yamaguti S. Systema Helminthum. New York: Interscience Publishers Inc.; 1959. (The Cestodes of Vertebrates; vol. 2).

Yamaguti S. Systema Helminthum. New York: Interscience Publishers Inc.; 1963. (Acanthocephala; vol. 5). 